\title{
"Theoretical foundations, practice, and empirical approaches to assessing the economy of happiness"
}

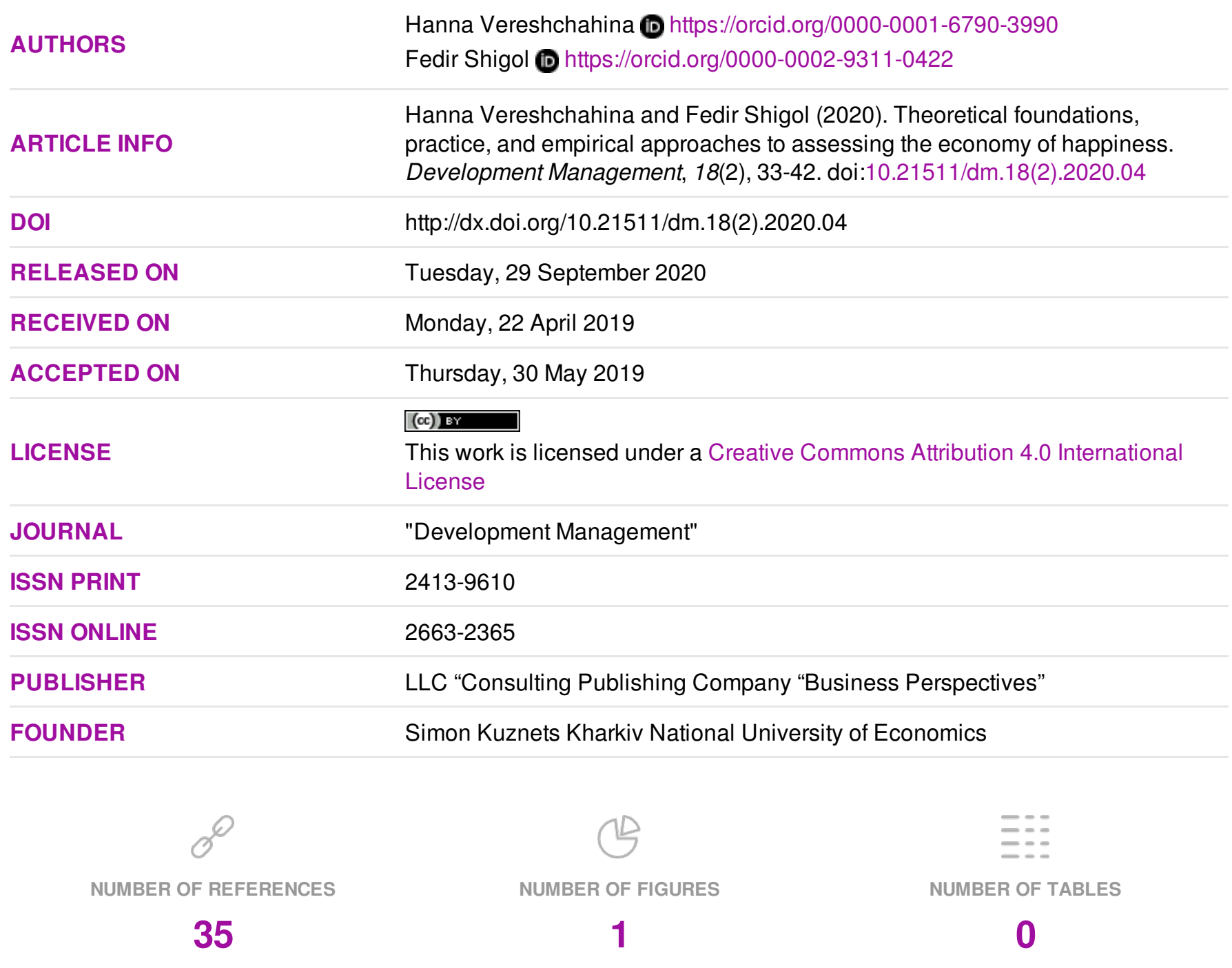

(C) The author(s) 2022. This publication is an open access article. 


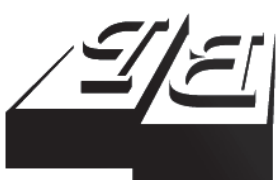

BUSINESS PERSPECTIVES

Publisher

LLC "CPC "Business Perspectives" Hryhorii Skovoroda lane, 10, Sumy, 40022, Ukraine www.businessperspectives.org



\section{S. KUZNETS KHNUE}

Founder

Simon Kuznets Kharkiv National University of Economics, Nauky avenue, 9-A, Kharkiv, 61166,

Ukraine

http://www.hneu.edu.ua/

Received on: 22nd of April, 2019 Accepted on: 30th of May, 2019

Published on: 29th of

September, 2020

(c) Hanna Vereshchahina, Fedir Shigol, 2020

Hanna Vereshchahina, Associate Professor, Department of Management, Logistics and Economics, Faculty of Management and Marketing, Kharkiv National University of Economics, Semen Kuznets, Ukraine.

Fedir Shigol, Associate Professor, Department of Management, Logistics and Economics, Faculty of Management and Marketing, Kharkiv National University of Economics, Semen Kuznets, Ukraine.

\section{(c) (i)}

This is an Open Access article, distributed under the terms of the Creative Commons Attribution 4.0 International license, which permits unrestricted re-use, distribution, and reproduction in any medium, provided the original work is properly cited.

\section{THEORETICAL FOUNDATIONS, PRACTICE, AND EMPIRICAL APPROACHES TO ASSESSING THE ECONOMY OF HAPPINESS}

\begin{abstract}
Since the end of the twentieth century, a new, relevant, and promising trend in economic science has been actively developing - the economy of happiness that arose at the junction of psychology and economics. Understanding the essence and content of social well-being is associated with such a development of a society where the social and spiritual needs of people are met, the resources and benefits of society are used as effectively as possible and favorable conditions for a full-fledged life and comprehensive development of each person are created. If earlier the main task and priority of any national policy was considered an intensive GDP growth, now the GNH - Gross National Happiness is increasingly considered as a priority, that is, the level of satisfaction with the life of the population, as evidenced even in the resolution of the UN General Assembly. However, the methodological approaches to assessing the economy of happiness are not perfect, first of all because this area is new in economic science. The study aims to summarize and further develop the principles and approaches to assessing the economy of happiness. The article analyzes existing practical approaches to the economy of happiness. A test was developed to assess the level of happiness of citizens from different countries; a survey was conducted based on this test from 2017 to 2018. Methodical approaches to assessing the economy of happiness have been improved based on obtaining correlation-regression models that show the dependence of happiness level on creativity, level of health, level of prosperity, level of satisfaction of needs, which enables to define creativity as the main factor affecting the level of happiness; and, unlike the known ones, it allows regulating the level of happiness as a final economic indicator.
\end{abstract}

\section{Keywords}

\section{JEL Classification}

economy of happiness, satisfaction with life, emotional well-being, level of satisfaction of needs, creativity

C51, I31, O10

\title{
ПРАКТИКА ЕКОНОМІКИ ЩАСТЯ ТА ЕМПІРИЧНІ ПІДХОДИ ДО ІІЇ ОЦНКИ
}

\begin{abstract}
Анотація
Починаючи з кінця XX-го століття активно розвивається новий актуальний і перспективний напрямок у економічній науці, який виник на стику психології та економіки, - економіка щастя. Розуміння сутності та змісту соціального благополуччя пов'язується з таким розвитком суспільства, при якому задовольняються соціальні та духовні потреби людей, максимально ефективно використовуються ресурси та блага суспільства, створюються сприятливі умови для повноцінного життя і всебічного розвитку кожної людини. Якщо раніше основною задачею і пріоритетом будь-якої національної політики вважалося зростання ВВП як кінцевого показника економічної діяльності, то наразі пріоритети зсовуються до такого показника як ВНЩ - Валового Національного Щастя, тобто рівень задоволеності життям населення стає головнішим, про це йдеться також у резолюції Генасамблеї ООН. Проте методичні підходи щодо оцінки економіки щастя не є досконалими, насамперед у зв'язку з тим, що цей напрям у економічній науці є новим. Мета дослідження полягає в узагальненні та подальшому розвитку засад і підходів щодо оцінки економіки щастя. У статті авторами проаналізовано наявні практичні підходи щодо оцінки економіки щастя. Розроблений тест для оцінки рівня щастя громадян різних країн, проведено опитування на базі цього тесту протягом 2017-2018 рр. Удосконалено методичні підходи щодо оцінки економіки щастя на основі отримання кореляційно-регресійцних моделей, які показують залежність рівня щастя від креативності, рівня здоров'я, рівня заможності, рівня задоволення потреб, що дає змогу визначити креативність як основний фактор, що впливає на рівень щастя; та, на відміну від відомих, дає змогу здійснювати регулюючий вплив на рівень щастя як кінцевий економічний показник.
\end{abstract}

Ключові слова

Класифікація JEL економіка щастя, задоволеність життям, емоційне благополуччя, рівень задоволення потреб, креативність 


\section{ВСТУП}

Останнім часом у західних дослідженнях економічного розвитку все більшого поширення набувають міждисциплінарні підходи. Починаючи з кінця XX-го століття активно розвивається новий актуальний $\mathrm{i}$ перспективний напрямок у економічній науці, який виник на стику психології та економіки, - економіка щастя. Розуміння сутності та змісту соціального благополуччя пов'язується з таким розвитком суспільства, при якому задовольняються соціальні та духовні потреби людей, максимально ефективно використовуються ресурси та блага суспільства, створюються сприятливі умови для повноцінного життя і всебічного розвитку кожної людини. Щастя як предмет наукового дослідження характеризується міждисциплінарністю, оскільки зазначена проблема стала характерною тенденцією розвитку економіки, філософії, соціології, психології, політики. Якщо раніше основною задачею і пріоритетом будь-якої національної політики вважалося зростання ВВП як кінцевого показника економічної діяльності, то наразі пріоритети зсовуються до такого показника як ВНЩ - Валового Національного Щастя, тобто рівень задоволеності життям населення стає головнішим, про це йдеться також у резолюції Генасамблеї

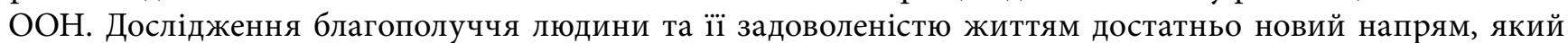
почав свій розвиток лише у 70-х pp. ХХ ст.: робота нобелівських лауреатів Сена [25] (1998 p. - «за внесок в економічну теорію добробуту»), Канемана [15], Сміта [27] (2002 р. - «за застосування психологічної методики в економічній науці, особливо при дослідженні формування суджень і прийняття рішень в умовах невизначеності»), Дітона [6] (2015 р. - «за аналіз споживання, бідності та добробуту»). Проте теоретичні та методичні підходи економіки щастя не є досконалими, насамперед у зв'язку з тим, що цей напрям у економічній науці $€$ новим. Все це зумовлює актуальність розглянутої теми.

Мета дослідження полягає в узагальненні та подальшому розвитку засад і підходів щодо оцінки економіки щастя.

\section{1. ЛІТЕРАТУРНИЙ ОГЛЯА}

Економічна теорія щастя - одне з нових напрямків сучасних досліджень, що базується на концепції обмеженої раціональності, запропонованої нобелівським лауреатом Саймоном [26]. У центрі уваги суб’єктивні уявлення особистості про задоволеність своїм життям як економічний феномен. Теорія розглядає економічнічинники імірувизначення ними людського щастя, яквоно залежить від економічного розвитку країни, які параметри відображають «рівень щастя» суспільства, як відчуття людиною власного щастя впливає на результативність його економічної діяльності, яка міра відповідальності за щастя самої особистості і держави. У центрі уваги - суб’єктивні уявлення особистості про задоволеність своїм життям як економічний феномен. Теорія розглядає економічні чинники і міру визначення ними людського щастя, як воно залежить від економічного розвитку країни, які параметри відображають «рівень щастя» суспільства, як відчуття людиною власного щастя впливає на результативність його економічної діяльності, яка міра відповідальності за щастя самої особистості і держави.

Концепція економіки щастя набуває все більшої популярності, дослідження, присвячені цьому аспекту економічних відносин, можна знайти у наукових роботах іноземних спеціалістів (Істерлін [7], Канеман [15], Освальд [22] та ін.). Ця теорія розглядає економічні та інші чинники, що визначають людське щастя, виявляє його залежність від рівня економічного розвитку країни, веде пошук параметрів оцінки рівня щастя суспільства в цілому. «Здавалося 6, слова «економічна теорія» і «щастя» не можуть перебувати в одному реченні, але багато дослідників починають пов'язувати ці поняття», - пише британський економіст Освальд [22]. Перші наукові розробки в галузі економічної теорії щастя з'явилися в 1970-х роках. Основи були закладені нобелівським лауреатом Канеманом [15] та американським економістом Істерліном [7]. Над різними аспектами економічної теорії щастя зараз працюють: Бленчфлауер [8], Кларк [2], Освальд [22]. Перша наукова конференція з «економікі щастя» відбулася в 1993 році у Лондонській школі економіки. Економічний розвиток, починаючи з останньої третини XX ст., по-різному впливає на щастя чоловіків і жінок: останні - щасливіші. Але, за результатами дослідження американського економіста Стівенсона [28], рівень щастя американських і європейських жінок, починаючи 3 1970-х років, знижується і наближається до «чоловічих» показників. Суб’єктивні уявлення про рівень щастя 
виявляються у ході соціологічних опитувань у роботах Бленчфлауера [8] і Освальда [22]. Доведенню необхідності включити в аналіз природні, а не лише раціональні мотивації поведінки економічних суб'єктів на мікрорівні, присвячені роботи Акерлофа [1].

Проте у науковій літературі не приділено достатньої уваги обгрунтуванню кількісної оцінки економіки щастя.

\section{2. МЕТА ДОСЛІДЖЕННЯ}

Мета дослідження полягає в узагальненні та подальшому розвитку засаді іпідходів щодо оцінки економіки щастя. Поставлена мета зумовила необхідність розв’язання наступних завдань: узагальнити наявні підходи економіки щастя; провести аналіз статистики економіки щастя в Україні та світі; розвинути методичні підходи щодо оцінки економіки щастя.

\section{3. МЕТОДИ ДОСЛІДЖЕННЯ}

Теоретичною та методологічною основою досліджень є наукові роботи фахівців у галузі «економіки щастя», положення теорії «економіки щастя»; методичні підходи до збору і аналізу статистичної інформації щодо рівня щастя в Україні та інших країнах; методи логічного узагальнення, методи аналізу і синтезу, методи співставлення та групування, методи кореляційного та регресійного аналізу, графічний - для візуалізації отриманих результатів.

\section{4. РЕЗУЛЬТАТИ ДОСЛІДЖЕННЯ}

\section{1. Узагальнення наявних теоретичних підходів «економіки щастя»}

Для початку зупинимося на «динаміці» щастя громадянина країни з розвинутою економікою $[23,22]$. У період активної трудової діяльності люди найменше задоволені життям: заради заробітку і кар'єри доводиться жертвувати задоволеннями. Зростання рівня щастя людей старших за 60 років (навіть через погіршення здоров'я) означає, що пенсійна система, охорона здоров’я тощо роблять комфортним життя літніх громадян розвинених країн. Фактори, що визначають суб'єктивну оцінку задоволеності життям, діляться на дві групи - неекономічні і економічні. До економічних факторів відносяться: ступінь економічного розвитку країни (доступність і якість медичних, освітніх, страхових послуг тощо), наявність роботи (джерел доходу), розмір індивідуального доходу, рівень середнього доходу на душу населення, показники інфляції та безробіття, коливання ділової активності в країні та світі.

Ступінь впливу кожного з перерахованих факторів на суб’єктивні уявлення про власне благополуччя різна. Значущим для щастя людини є робота. Втрата робочого місця призводить до падіння доходу і самооцінки, погіршення настрою, зміни розпорядку дня завдають серйозної шкоди емоційному благополуччю більшості людей. Це справедливо не лише для жителів розвинених західних країн, але і для країн Азії, Африки і Латинської Америки.

Щастя полягає не лише у грошах, їх купівельній спроможності. Неекономічні чинники також важливі і дуже різноманітні. Це формальні ознаки: вік, стать, індивідуальні якості особистості (що визначають їі, наприклад, як екстраверта або інтроверта, оптиміста або песиміста), соціальний статус (освіта, професія, сімейний стан), спосіб проводити час (спілкування з близькими і друзями, заняття спортом або хобі тощо), життєві умови (клімат і стан навколишнього середовища, соціальне розшарування, правопорядок тощо). Їх вплив на рівень щастя неоднозначно і може істотно відрізнятися в різних країнах.

Наприклад, фактор - освіта. Дослідження, проведені у Великобританії, показують: люди 3 університетським дипломом менш задоволені своїм життям і в більшій мірі схильні до стресів, ніж особи без вищої освіти [14]. Проте позитивна кореляція між рівнем освіти і рівнем щастя спостерігається в багатьох країнах (США, Швейцарія і країни Латинської Америки). 
Виявлення чинників щастя представляє самостійний дослідницький інтерес, але для створення наукової економічної концепції необхідний кількісний аналіз. Економічна теорія щастя використовує ординалістський (порядковий) підхід, який базується на «моделі упорядкування суб'єктивних оцінок». Треба вказати порядковий номер свого рівня щастя. Об'єктивність досліджень залежить від виконання передумови про те, що всі індивіди мають схожі уявлення про щастя і про спосіб приписувати суб'єктивними оцінками власного емоційного стану відповідний порядковий номер. На базі «моделі упорядкування суб'єктивних оцінок» були отримані результати, що дають уявлення про статистичний розподіл щасливих людей країн, а також про те, від яких чинників залежить емоційне благополуччя.

Як показано у Освальда [22] - у середньому ментальний добробут громадян країни тим вище, чим вище ВВП. Кореляції між ВВП і рівнем щастя, на думку Освальда [22], недостатньо для підтвердження того, що суб'єктивна оцінка дає об'єктивне уявлення про якість життя. Для перевірки дослідники узагальнили дані американської системи нагляду за факторами поведінкового ризику (BRFSS [5]) за 2005-2008 pp. Як вважають економісти, а також медики, соціологи, екологи та інші дослідники, у BRFSS [5] відображені об'єктивні параметри «якості життя». 3 іншого боку, об'єктивними параметрами «якості життя» були протиставлені узагальнені суб'єктивні оцінки людьми своєї задоволеності життям за чотирибальною шкалою: (4) - «дуже задоволений», (3) - «задоволений», (2) - «не задоволений», (1) - «зовсім не задоволений». На основі побудованої статистичної моделі був зроблений висновок, що «суб’єктині уявлення про добробут дають вичерпну інформацію про якість людського життя».

Досвід переходу до ринкової економіки у країнах Східної Європи ілюструє вплив різких коливань ВВП на рівень емоційного благополуччя. Істерлін [7] узагальнив результати емпіричних досліджень: | у 1990-ті роки в постсоціалістичних країнах Східної Європи падіння ВВП і зниження рівня задоволеності життям корелювали. Задоволеність життям найсильніше знизилася серед найменш освічених жителів і людей старших за 30 років. Але підвищення економічного рівня не призвело до зростання задоволеності життям: у 2005 році середній рівень ВВП на 25\% перевищив показник початку 1990 -х років, а задоволеність життям хоча і наблизилася до докризового рівня, але залишалася нижчою. Цей факт Істерлін [7] пояснив тим, що зростання задоволеності матеріальними умовами життя в постсоціалістичних країнах збігається зі зниженням задоволеності людей від роботи, стану здоров'я і сімейного життя внаслідок підвищених трудових навантажень і стресів.

Дослідники підтверджують, що щастя потрібно вимірювати за допомогою індикаторів, які в залежності від джерел умовно можна розділити на дві групи: суб’єктивні (опитування людей) і об’єктивні (медичні та економічні параметри). Часто суб’єктивні уявлення про рівень щастя виявляють у ході соціологічних опитувань. У роботах Бленчфлауера [8] і Освальда [22] за 1972-2008 рр. були отримані наступні результати: 32\% опитаних американців відповіли, що вони «дуже щасливі», 56\% - «досить щасливі», 12\% - «не дуже щасливі».

Як показують аналогічні опитування, проведені у різних країнах, більшість жителів розвинених країн відповідають, що вони досить задоволені своїм життям. Людське щастя також має непрямі, але об’єктивні вимірювачі, до яких відносяться індикатори певних процесів в організмі.

Наприклад, дослідження в області фізіології свідчать про зв’язок благополуччя з захисними силами організму: чим щасливіша людина, тим легше їі організм пручається вірусних інфекцій; у емоційно врівноважених людей виявляється менше число індикаторів запальних процесів в організмі. Дані медичних обстежень можуть дати уявлення про рівень щастя людей і допомогти систематизувати дослідження емоційного благополуччя. Так, наявність статистичної взаємозалежності між відчуттям щастя і показниками захворюваності на гіпертонію у 2008 році довели Бленчфлауер [8] і Освальд [22]. Медичні параметри відносяться до об’єктивних індикаторах емоційного благополуччя індивідів. Медичні дані мають особливий економічний сенс: вони показують, як працюють і який стрес, пов'язаний із професійною діяльністю, відчувають люди.

Істотний економічний аспект мають знакові події в житті людини. Так, напередодні весілля відбувається різке зростання рівня щастя жінки, який потім різко падає. Аналогічно, напередодні розлучення спостерігається зниження ментального благополуччя подружжя, але потім зростає рівень щастя. В 
очікуванні появи дитини у майбутніх батьків вище душевне благополуччя, проте після народження малюка рівень щастя знижується до колишніх позначок. Всі події, що відбуваються в людському житті, впливають на оцінку людьми власного рівня щастя і відбиваються на їхній економічній результативності.

У 2005 році американські психологи оприлюднили результати свого дослідження про те, що щаслива людина отримує більшу користь від своєї роботи. Вона схильна до творчих ідей, менше втомлюється, а iї ентузіазм приносить більший дохід. Доведенню необхідності включити в аналіз природні, а не лише раціональні мотивації поведінки економічних суб'єктів на мікрорівні, присвячені роботи Акерлофа [1].

Щастя - це не просто результат успіху, очевидний також чіткий зворотній взаємозв'язок, який полягає в тому, що більший успіх в житті - результат щастя. Але яка роль держави? Один із варіантів відповідей: роль держави - «підказувати» людям, що їм необхідно робити, щоб стати й залишатися щасливими.

Проведене узагальнення теоретичних підходів дозволає говорити про те, що економічна теорія щастя пропонує важливі висновки для економічної теорії в широкому сенсі. «Економіка щастя» показує, що для найбідніших країн і країн з ринками, що розвиваються, підвищення ВВП може вирішити два завдання підвищення матеріального добробуту і поліпшення ментального благополуччя громадян. Що стосується розвинених країн, то, оскільки в них проблема досягнення високого рівня матеріального добробуту вирішена, на перший план виходить проблема підвищення ментального благополуччя. Сюди входять як економічні так і неекономічні фактори. Сьогодні вже недостатньо говорити про те, що економічна теорія досліджує тільки проблему раціонального використання обмежених ресурсів для максимального задоволення матеріальних потреб людей. Економічна теорія повинна описувати шляхи максимізації щастя людства.

\section{2. Аналіз статистики економіки щастя}

Існуєзалежність міжзаможністю та щастям, алеж країни з майжеоднаковим рівнем ВВПхарактеризуються різним рівнем щастя [34].

За матеріалами World Values Survey [35], на рівень щастя суттєвий вплив здійснює також рівень довіри у суспільстві, а також те, наскільки громадяни окремих країн у своєї більшості відчуваються щасливими або ж нещасними.Країни світу мають свій рейтинг за рівнем щастя за результатами дослідження у межах дослідницького проекту міжнародної програми «Мережа рішень сталого розвитку», який вимірює показник щастя населення у країнах світу (World Happiness Report [34]). Дослідження проводиться чинним при Колумбійському університеті дослідним центром «Інститут Землі» (The Earth Institute) під егідою Організації Об'єднаних Націй у рамках глобальної ініціативи «Мережа рішень сталого розвитку» (UN Sustainable Development Solutions Network [29]).

Отже, підсумовуючи узагальнений матеріал, хотілось би зазначити, що щастя - індивідуальне для кожної людини. Не існує універсальних показників для вимірювання щастя, що могли б дати точний результат, тому теоретичні підходи оцінки щастя потребують удосконаленння та підвищення обгрунтованості.

\section{3. Розвиток теоретичних засад і підходів економіки щастя}

Дослідження показали, що основні фактори суб’єктивного благополуччя - життя у стабільному демократичному суспільстві, забезпеченість у матеріальному плані; друзі й сім'я; цікава робота, що дає гідну оплату праці; здоров'я і доступне лікування; наявність життєвих цілей, важливих з точки зору власної системи цінностей; філософія чи релігія, що дає напрямок, мета і сенс життя. Набір і кількість задоволених потреб не можуть служити характеристикою щасливого життя. Традиційні показники добробуту країни - ВВП на душу населення або ІРЛП - це узагальнені параметри національних економік, їх поліпшення нелінійно пов’язане з добробутом окремих громадян. Тому потрібен можливо інший показник, який вийшов би за матеріальний кордон і відбивав інші важливі аспекти життя людини. Прихильники економічної теорії щастя пропонують в якості альтернативного індикатора прогресу розраховувати рівень сукупного щастя громадян. Звичайно, рівень щастя не стане єдиним показником людського розвитку, але це важливе доповнення до інших індикаторів. Першопроходцем в альтернативному дослідженні параметрів розвитку стало невелике гімалайське королівство Бутан [1]. 
У 1972 р замість ВВП король цієї країни Джігме Синг Вангчук рекомендував вимірювати добробут таким показником, як валове національне щастя (ВНЩ), що включає наступні компоненти: забезпечення справедливого і соціально-економічного розвитку; збереження і розвиток традиційних культурних цінностей; охорона природи; правильне управління країною.

Конкретною пропозицією з оцінки рівня щастя можна вважати Міжнародний індекс щастя (англ. Нарру Planet Index) [11]. У міжнародному індексі щастя якість життя визначається матеріальними і духовними показниками. Для розрахунку індексу використовуються такі показники як: суб'єктивна задоволеність життям, очікувана тривалість життя, екологічна обстановка:

Happy Planet Index $\approx$ (Суб'єктивне благополуччя × Тривалість життя $\times$ Нерівність) / (Екологічний слід).

Цей індекс покликаний визначити наскільки ефективно різні країни можуть використовувати ресурси, щоб забезпечити щасливе життя своїм громадянам.

Результати міжнародного дослідження показують: жодна з розвинених країн не входить у першу десятку, причиною цього $є$ високі значення індикатора екологічного сліду, який відображає міру негативного впливу людини на навколишнє середовище. Укладачі «рейтингу щастя» повідомляють, що в ході дослідження були виявлені принципи, які доводять, що рівень особистого добробуту і щастя жодним чином не прив'язаний до кількості споживаних ресурсів.

Але виникають деяки питання щодо розрахунків рівня щастя за цією формулою. По-перше, хотілось би зазначити, що оцінка тривалості життя може давати зсунення оцінки, тому, що крива, що показує залежність рівня щастя від віку, має U-подібну форму $[22,23]$. Тож не можемо стверджувати, що чим більше (чим менше) вік, тим щасливіша людина. По-друге, викликає питання фактор «екологічний слід». Згідно з поясненнями, екологічний слід - середній вплив, який кожен житель країни несе на навколишнє середовище країни, на основі даних Global Footprint Network [22] (екологічний слід виражають у гектарах (га) на людину). Проте жителі однієї країни, або групи країн можуть забруднювати навколишне середовище іншої країни. Тобто, вимірювання щастя таким чином не є досконалими. Хотілось би зазначити, що кожна людина має свої пріорітети в оцінці щастя. Виходячи з цього, автори створили опитування, яке можуть пройти жителі країн. Таке опитування було створене авторами за допомогою Google форми. До нього залучилися жителі різних країн. На Рисунку 1 представлено розподіл опитаних за тестом.

За результатами опитування авторами було побудовано кореляційно-регресійні моделі залежності рівня щастя від досліджуваних факторів. Для всіх рівнянь було перевірено параметри моделі на статистичну значущість, статистична значущість наявна. У опитуванні у 2017 році взяли участь жителі 23 країн віком від 12 до 65 років, у 2018 році взяли участь жителі 25 країн віком від 12 до 67 років.

Отримані авторами моделі, які показують залежність рівня щастя від:

2017 рік:

Креативності $(x 1): \mathrm{y}=-0.0618 \times 12+10.936 x 1-407.31, \quad R^{2}=0.8142$.

Рівня здоров’я $(x 2): \mathrm{y}=-0.0038 \times 23+0.7486 \times 22-47.649 \times 2+1,035.3, \quad R^{2}=0.5779$.

Рівня заможності $(x 3): \mathrm{y}=-0.0466 \times 32+7.8478 \times 3-260.21, R^{2}=0.6747$.

Рівня задоволення потреб $(x 4): \mathrm{y}=-0.0372 x 42+6.6125 x 4-222.48, R^{2}=0.6218$.

2018 рік:

Креативності $(x 1): \mathrm{y}=-0.0620 x 12+10.942 \times 1-407.35, R^{2}=0.8151$.

Рівня здоров'я $(x 2): \mathrm{y}=-0.0039 \times 23+0.7491 \times 22-47.749 \times 2+1,042.3, R^{2}=0.5785$.

Рівня заможності $(x 3): \mathrm{y}=-0.0473 \times 2+7.8484 x-260.24, R^{2}=0.6754$.

Рівня задоволення потреб $(x 4): \mathrm{y}=-0.0377 x 42+6.6126 x 4-222.52, R^{2}=0.6223$. 1 Примітки: Опитування доступне за посиланням $\quad$ https://docs.google.com/forms/d/e/1FAIpQLSfzAv1bIPnTSo_tahRF-nH-
A0PI7PRQmmOJsE5TiZbO67NVnw/viewform?c=0\&w=1. 
What country do you live in? (З якої Ви країни?)

308 ответов



How old are you? (Скільки Вам років?)

308 ответов



\section{Evaluate your happiness level (Оцініть Ваш рівень щастя).} 308 ответов
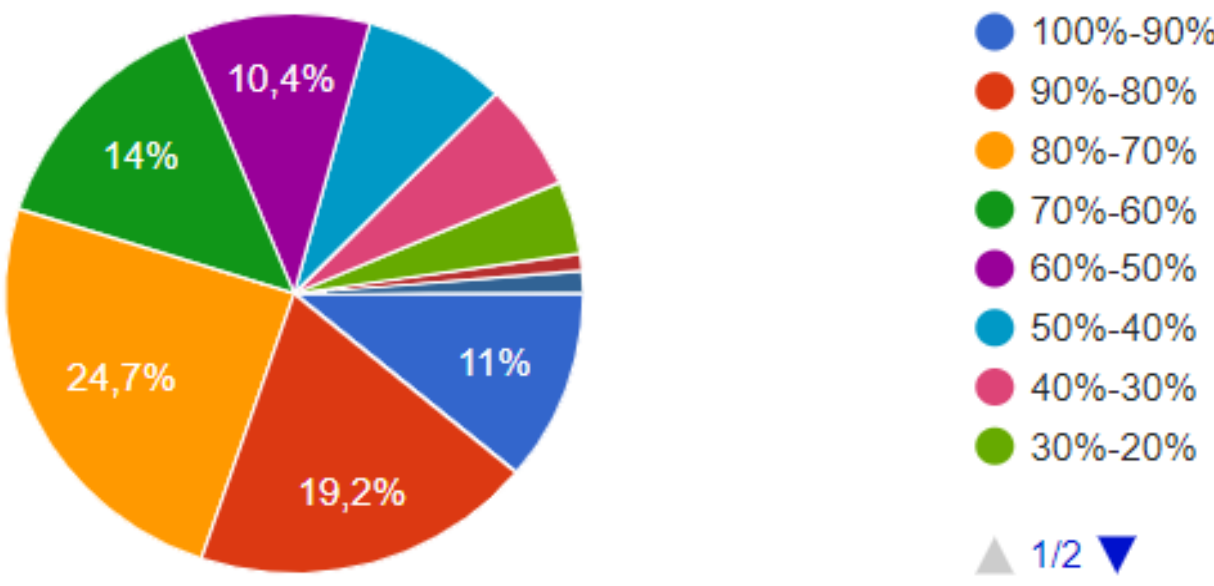

Джерело: Складено авторами на основі даних, отриманих за результатами опитування.

Рисунок 1. Розподіл опитаних за тестом 


\section{Evaluate your health level (Оцініть Ваш рівень здоров'я).}

\section{8 відповідей}

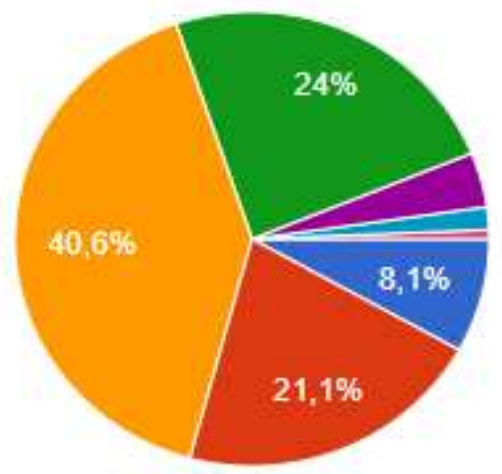

100\%-90\%-excellent (відмінне).

$90 \%-80 \%$-very good(дуже добре).

$80 \%-70 \%$-pretty good (доволі добре).

$70 \%-60 \%$-fine (добре).

- $60 \%-50 \%$-not good(непогане).

$50 \%-30 \%$-bad (погане).

- $<30 \%$-gruesome (дуже погане)

Do you completely satisfy your needs and wishes? (Чи повністю Ви задовольняєте свої потреби та бажання?)

308 відповідей

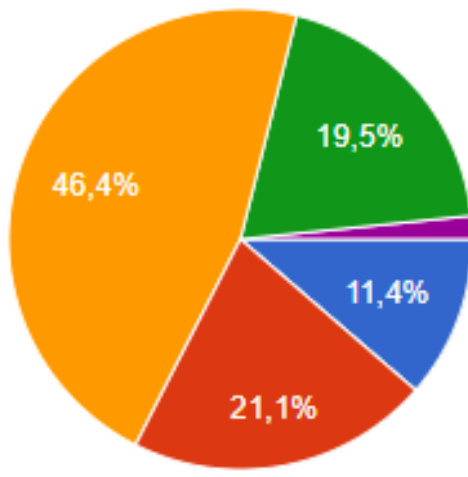

$100 \%-90 \%$.

$90 \%-75 \%$.

$75 \%-60 \%$

$60 \%-40 \%$.

$<40 \%$

\section{Are you rich?(Ви заможні?)}

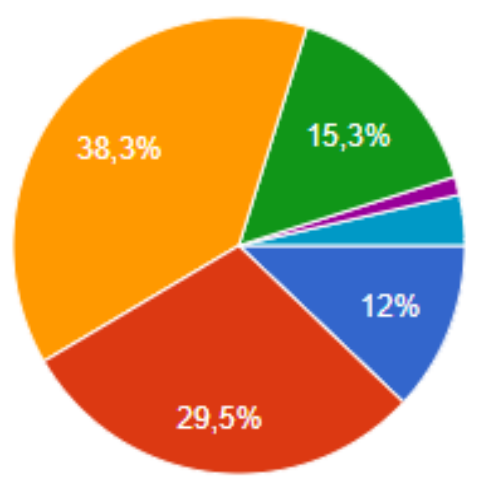

Yes, I earn MUCH more than I expend (Так, я заробляю НАБАГАТО біль.

Yes, I earn more than I expend (Так, Я заробляю більше, ніж витрачаю).

So-so, I earn as many as I expend(Недостатньо, я заробляю...

No, I earn less than I expend $(\mathrm{Hi}, я$ заробляю менше, ніж витрачаю).

No, I poor (Hi, я бідний).

I don't earn (Не заробляю).

Рисунок 1 (продовження). Розподіл опитаних за тестом 
Проведені дослідження дають змогу визначити креативність як основний фактор, що впливає на рівень щастя; та на відміну від відомих підходів, дають змогу здійснювати регулюючий вплив на рівень щастя як кінцевий економічний показник.

\section{ВИСНОВКИ}

Проведене дослідження показало, що найбільший вплив на рівень людського щастя несуть неекономічні чинники. Люди, що були креативні, мали улюблену справу і підтримку, не будучи достатньо заможними, були на рівень щасливіші за багатих, що цього не мали. «Економіка щастя» чітко показує, що для найбідніших країн і країн з ринками, що розвиваються, підвищення ВВП може вирішити два завдання підвищення матеріального добробуту і поліпшення ментального благополуччя громадян. Що стосується розвинених країн, то, оскільки в них проблема досягнення високого рівня матеріального добробуту вирішена (високий рівень доходу на душу населення, низька дитяча смертність, для кожного жителя відкритий доступ до освіти і медичного забезпечення, гарантовані цивільні права і свободи), на перший план виходить проблема підвищення ментального благополуччя. Як виявилось у ході опитування, дуже важливим чинником $є$ підтримка близьких. Тож необхідно змінювати своє ставлення до оточуючих, на що може вплинути тільки індивід.

Таким чином, у статті узагальнено та критично проаналізовано наявні підходи економіки щастя.

Практичне значення отриманих результатів полягає у розробленні тесту для оцінки рівня щастя громадян різних країн та проведенні опитування на базі цього тесту протягом 2017-2018 pp.

Практичне значення отриманих результатів полягає у побудові кореляційно-регресійних моделей залежності рівня щастя від таких факторів як: креативність, рівень здоров’я, рівень заможності, рівень задоволення потреб, які дають змогу визначити креативність як основний фактор, що впливає на рівень щастя; та, на відміну від відомих підходів, дають змогу здійснювати регулюючий вплив на рівень щастя як кінцевий економічний показник.

У подальших дослідженнях планується розробити тест з розширенням переліку факторів, які можуть впливати на рівень щастя людей за професійним спрямуванням та соціальним статусом/станом, та провести опитування населення у розрізі окремих професій та галузей промисловості; побудувати кореляційно-регресійні моделі залежності рівня щастя людей за професійним спрямуванням та соціальним статусом/станом.

\section{СПИСОК ЛІТЕРАТУРИ}

1. Akerlof, G. (2001). Behavioral macroeconomics and macroeconomic behavior (Nobel Prize in Economics documents, No 2001-4) (30 p.). Retrieved from https://econpapers.repec.org/paper/risnobelp/2001_5f004.htm

2. Andrew, C., Flèche, S., Layard, R., Powdthavee, N., \& Ward, G. (2018). The origins of happiness: the science of well-being over the life course. NJ: Princeton University Press. Retrieved from https://www.amazon.com/Origins-Happiness-Science-Well-Being-Course/ $\mathrm{dp} / 0691177899$

3. Bärnighausen, T., Liu, Y., Zhang, X., \& Sauerborn, R. (2007). Willingess to pay for social health insurance among informal sector workers in Wuhan, China: A contingent valuation study. BMC Health Services Research, 114(7). https://doi.org/10.1186/1472-6963-7-114

4. Butko, M., Nezhyvenko, A., \& Pepa, T. (2016). Ekonomichna psykholohiia [Economic psychology]. Kyiv: Tsentr uchbovoi literatury. (In Ukrainian)

5. Centers for disease control and prevention (2018). Behavioral risk factor surveillance system. Retrieved from https://www.cdc.gov/brfss/ index.html

6. Deaton, A. (2015). The great escape: health, wealth, and the origins of inequality (376 p.). Retrieved from https://www.amazon.com/GreatEscape-Health-Origins-Inequality/dp/0691165629

7. Easterlin, R., McVey, L., Switek, M., Sawangfa, O., \& Zweig, J. (2010). The happiness-income paradox revisited. Proc Natl Acad Sci U S A, 107(52), 22463-22468. https://doi.org/10.1073/pnas.1015962107

8. Freeman, R., \& Blanchflower, D. (2000). Youth Employment \& Joblessness in Advanced Countries (440 p.). USA: University of Chicago Press. Retrieved from https://www.nber.org/chapters/c6799 
9. Gallup International Association (2017). Official website. Retrieved from http://www.gallup-international.com

10. Global Footprint Network (2018). Official website. Retrieved from https://www.footprintnetwork.org

11. Happy Planet Index (2012). The Happy Planet Index: 2012 Report. A global index of sustainable well. Retrieved from https://neweconomics. org/uploads/files/d8879619b64bae461f_opm6ixqee.pdf

12. Happy Planet Index (2018). Official website. Retrieved from http://happyplanetindex.org

13. Icaro, J., Pereira, R., \& Freire, I., etc. (2017). Stress and quality of life among university students: a systematic literature review. Health Professions Education, 4(2), 70-77. http://dx.doi.org/10.1016/j.hpe.2017.03.002

14. Institute for social and economic research (2018). Official website. Retrieved from https://www.iser.essex.ac.uk/bhps

15. Kahneman, D. (2011). Thinking, fast and slow (499 p.). New York City: Brockman, Inc.

16. Kennet, H. (1976). Ekonomichni teorii ta tsili suspilstva [Economic theories and goals of society] (405 p.). Moscow: Prohres. (In Ukrainian)

17. Kolodko, Hzh. (2009). Mir v dvizhenii [World in motion] (576 p.). Moscow: Mahistr. (In Russian)

18. Lavrova, N. (2006). Ekonomika schastya [Economy of happiness]. Nauka i zhizn-Science and life. (In Russian). Retrieved from http:// www.nkj.ru/archive/articles/5242/

19. Lejard, R. (2012). Schastye. Uroki novoy nauki [Happiness. Lessons of a new science] (416 p.). Moscow: Instytutu Hajdara. (In Russian)

20. Newsru.com (2004). Butan: strana, zamenivshaya VVP indikatorom «valovogo natsionalnogo schastya» [Bhutan: a country that has replaced GDP with an indicator of "gross national happiness»]. (In Russian). Retrieved from http://www.newsru.com/finance/11oct2004/butan. html

21. Nikilieva, N., Smiesova, V., \& Ruban, O. (2017). Ekonomika shchastia: suchasni napriamy rozvytku ta perspektyvy realizatsii v Ukraini [Economy of happiness: modern directions of development and prospects of realization in Ukraine]. International scientific conference «Economy and Management: Modern Transformation in the Age of Globalization» (pp. 9-12). Lithuania: Klaipeda University. (In Ukrainian). Retrieved from http://dspace.uccu.org.ua/bitstream/123456789/5908/1/\%D0\%9A\%D0\%BB\%D0\%B0\%D0\%B9\%D0\%BF\% D0\%B5\%D0\%B4\%D0\%B0-\%D0\%9B\%D0\%B8\%D1\%82\%D0\%B2\%D0\%B0-\%D0\%BC\%D0\%B0\%D1\%80\%D1\%82\%202017\%20 \%D1\%87\%D0\%B0\%D1\%81\%D1\%82\%D1\%8C\%201.pdf

22. Oswald, A. (2009). Emotional Prosperity: Invited BJIR Annual Lecture at LSE. Retrieved from https://slideplayer.com/slide/679622

23. Rodionova, L. (2015). Age characteristics of the happy life in Russia and Europe: The econometric approach. Applied Econometrics, 40(4), 64-83. Retrieved from http://pe.cemi.rssi.ru/pe_2015_4_64-83.pdf

24. Sachs, J. (2011). The economics of happiness. Retrieved from https://www.project-syndicate.org/commentary/the-economics-ofhappiness?barrier=accesspaylog

25. Sen, A. (1986). Welfare Economics and the Real World. Acceptance paper for the Frank Seidman Distinguished Award in Political Economy (198 p.). Memphis: F.K. Seidman Foundation.

26. Simon, H. (1994). Administrative behavior: how organizations can be understood in terms of decision processes computer science (11 p.). Roskilde: Roskilde University. Retrieved from https://pdfs.semanticscholar.org/a78c/493ee0e8c9dfe7bd0fbaa2ef0ca2c8aa4562.pdf

27. Smit, A. (1997). Teoriya nravstvennykh chuvstv [The theory of moral feelings] (351 p.). Moscow: Respublika. (In Russian)

28. Stevenson, B., \& Zlotnick, H. (2016). Representations of men and women in introductory economics textbooks. Retrieved from http://fordschool.umich.edu/files/stevenson-manuscript-textbooks.pdf

29. Sustainable Development Solutions Network (2018). Official website. Retrieved from http://unsdsn.org

30. The nobel prize (n.d.). The prize in economic sciences 2015. Retrieved from https://www.nobelprize.org/prizes/economic-sciences/2015/ summary

31. United Nations (2011). Rezolyutsiya, prinyataya Generalnoy Assambleyey 19 iyulya 2011 goda: Schastye: tselostnyy podkhod k razvitiyu [Resolution adopted by the General Assembly on July 19, 2011: Happiness: a holistic approach to development]. (In Russian). Retrieved from http://www.un.org/ru/documents/ods.asp?m=A/RES/65/309

32. World Database of Happiness (2018). Official website. Retrieved from https://www.worlddatabaseofhappiness.eur.nl/index.html

33. World Happiness Report (2016). World Happiness Report 2016. Retrieved from https://worldhappiness.report/ed/2016/

34. World Happiness Report (2018). World Happiness Report 2018. Retrieved from http://worldhappiness.report/ed/2018/

35. World Values Survey (n.d.). Official website. Retrieved from http://www.worldvaluessurvey.org/wvs.jsp 